\title{
Effects Of E-Commerce On The Sharia Hotels Brand Awareness In Bandung
}

\author{
Muchyidin Natakusuma \\ Department of Business Administration Padjadjaran University, \\ Bandung, Indonesia \\ Ria Arifianti \\ Department of Business Administration Padjadjaran University, \\ Bandung, Indonesia \\ Iwan Sukoco \\ Department of Business Administration Padjadjaran University, \\ Bandung, Indonesia
}

\begin{abstract}
Sharia has become global, including the development of Sharia Hotels. In addition, the development of internet technology in Indonesia can be seen with the existence of ecommerce which benefits in the form of business convenience because the internet is seen as an advertising media that is cheaper, more efficient and effective. Tight business competition has made brand as an important aspect that can be a benchmark for a company. Sharia hotel owners use e-commerce to build strong brands and make consumers acknowledge that their brands are well received by consumers. This study aims to find out how e-commerce influences brand awareness in Narapati Indah Sharia Boutique Hotel and Convention Bandung. Respondents in this study were sampled using the Structural Equation Modeling (SEM) method that allows testing a series of relatively complex relationships simultaneously. The results showed that respondents' responses regarding e-commerce and brand awareness at Narapati Indah Sharia Hotel were in the good category. In addition, there is a significant influence between ecommerce on brand awareness in Narapati Indah Sharia Hotel especially through their own website so that to depend on other parties are no longer needed.
\end{abstract}

Keywords: e-commerce, brand awareness, sharia hotels

\section{INTRODUCTION}

Sharia is a system in an institution, agency, or company with Islamic law compliant. This system was formerly only applied to the production of basic needs, such as food, medicine and cosmetics. However, currently the Islamic system is also applied in various industries, such as the banking and the tourism industry. Developing a hotel with a sharia concept is very different from developing a conventional hotel. To establish a hotel with sharia concept, there are several requirements that must be known, such as the principle of sharia itself which refers to Islamic principles. Sharia hotel development also has an important role in changing the bad image of hospitality in Indonesia.

Tourists in Bandung, especially during holidays, are the target of hotels in Bandung. Various concepts and services are offered to attract consumers. In Bandung there are not many hotels that serve sharia features. The presence of sharia hotels affects tourists in the city of Bandung to feel more comfortable and safe. Tourists who stay in sharia hotels can choose the location of the place of accommodation as desired. Although the number of sharia-compliant hotels has 
not been as much as conventional hotels, but there are quite a lot of enthusiasts. Following are Sharia Hotels in Bandung:

Table 1.1

Sharia Hotels in Bandung City

\begin{tabular}{|c|l|}
\hline No. & \multicolumn{1}{|c|}{ Sharia Hotels } \\
\hline 1 & Narapati Indah Sharia Hotel \\
\hline 2 & Daarul Jannah Hotel \\
\hline 3 & Cinnamon Hotel Boutique Sharia \\
\hline 4 & Lingga Hotel Sharia \\
\hline 5 & Noor Hotel Sharia \\
\hline 6 & Orange Home's Sharia \\
\hline 7 & Ruby Hotel Sharia \\
\hline
\end{tabular}

Source: Staff of the Bandung City Department of Culture and Tourism 2018

Information Technology is developing based on the demands of the community. The internet is a media that has its own appeal and excellence for individuals and organizations. That can be shown through convenience, 24 hours access, efficiency, data speed, unlimited choices, and potential sources of information and technology. In the business market, the internet has a great impact to create new breakthroughs, namely digital marketing. Tight business competition, surely brands have become an important aspect of a company. This can be a company benchmark whether a company is well known or not to its customers. The extent to which products or services owned by companies are well known by their customers is called brand awareness (Kaser, 2012: 120). The use of social media is also closely related to brand awareness where when the use of social media goes well, of course affects to a better company brand awareness.

In general, consumers are less familiar with sharia-compliant hotels, because some consumers think that sharia hotels are intended only for Muslims. On the contrary, sharia-compliant hotels promise a healthy lifestyle and ensure comfort for their guests, so there is no limitation of who is allowed to stay at the hotel. Thus, it is necessary for sharia hotel managers to do ecommerce as a media that supports to make a well-known brand in the community both from local and foreign tourists, so that consumers are well-stocked on sharia-based hotels. Branding as explained by (Maulana, 2015) is a collection of communication activities carried out by companies in the process of building and raising brands. Branding is not only focus on attracts the targets to choose this sharia hotel, but on the other hand, it is even more important that consumers can view sharia-compliant hotels as the best hotel choices that can provide new features in hospitality.

Narapati Indah Sharia Hotel is one of the sharia hotels in Bandung that focused in building sharia-compliant hotel branding. Various marketing strategies have been carried out in building brand awareness, especially through e-commerce media. Narapati Indah Sharia Hotel has used e-commerce in building brand awareness of sharia hotels for a long time in the past five years. The following e-commerce media used by Narapati Indah Sharia Hotel are through websites such as www.narapati.com, www.traveloka.com, www.agoda.com, www.klikhotel.com, www.pegipegi.com, www.rajakamar.com. Currently, e-commerce either from the hotel website itself or Online Travel Agent (OTA) considered very effective by Narapati Indah Sharia Hotel Bandung in building brand awareness and in marketing. This is evidenced by the occupancy of the Narapati Indah Sharia Hotel Bandung Hotel which is almost $80 \%$ generated from e-commerce media while $20 \%$ by coming directly to the hotel.

Occupancy of visitors of Narapati Indah Sharia Hotel is still fluctuating from the target set by the Indah Sharia Hotel Managers. In 2017, it has experienced a very significant decline in the 
last 5 years. This is in line with visitor brand awareness of Narapti Indah Sharia Hotel. The public or visitors awareness to Narapati Indah Sharia Hotel as a sharia-compliant hotel in Bandung is still lacking. The regular guests contribute significantly to the hotel income level. Regular guests are the attention of hotel managers. That is because generally, regular guests are customers who understand sharia services or features in Narapti Indah Sharia Hotel Bandung. E-commerce media contributes to the aspect of branding, especially in describing information on sharia hotel services that are applied by the Sharia Indah Sharia Hotel Bandung. Descriptions on the internet as the starting point for educating the public about shariacompliant hotel services that apply certain terms and conditions the staying guests (Narapati Indah Sharia Hotel, 2018).

\section{RESEARCH METHODS}

The method applied in this research is descriptive verification method. Descriptive method is used to describe or describe problems related to questions about e-commerce, while verification analysis is an analysis and verification model to find out the truth of the proposed hypothesis. Verification research in this study is to determine the effect of e-commerce on brand awareness. In addition, this study uses a quantitative approach. Data in the study were obtained by collecting samples, as well as sample collection techniques in research through field research and library research. In addition, testing the validity and reliability was conducted to test and verify research instruments in this study. Verification analysis method used to examine a particular population or sample, data collection using research instruments, data analysis is quantitative/statistic, with the aim of testing predetermined hypotheses using Structural Equation Modeling (SEM) method or the Structural Equation Model with the AMOS program. SEM is a set of statistical techniques that allow testing of a series of relatively complex relationships simultaneously. Complicated relationship can be interpreted as a series of relationships that are built between one or several dependent variables (endogenous) with one or several independent variables (exogenous), and these variables take the form of factors or constructs that are constructed from several indicators observed or measured directly. The unit of analysis in this study is Narapati Indah Sharia Hotel. Narapati Indah Sharia Hotel is a sharia hotel in Bandung that uses e-commerce to build the brand awareness. In this study, the research population was a subject related to e-commerce and the brand awareness. Based on the SEM analysis compliance, according to Santoso (2015) using the technique of maximum likeness estimation (MLE) where the minimum number of required and representative samples minimum of 200 samples. Respondents in this study were the guests of Narapati Indah Sharia Hotel who stayed using e-commerce as many as 233 people.

\section{Profile of Respondents}

\section{RESEARCH RESULTS AND DISCUSSION}

The following are the results of the demographics of Narapati Indah Sharia Hotel guests staying overnight using e-commerce based on gender, age, monthly income, latest education, origin and where to buy rooms at Narapati Indah Sharia Hotel.

Table 1.2

Gender of Respondents

\begin{tabular}{|c|c|c|}
\hline Gender & Frequency & Percentage (\%) \\
\hline Male & 169 & 72.53 \\
\hline Female & 64 & 27.47 \\
\hline Total & $\mathbf{2 3 3}$ & $\mathbf{1 0 0}$ \\
\hline
\end{tabular}

Source: Data Processing Results, 2018

Based on the table above, it can be seen that the tendency of the number of guests staying at Narapati Indah Sharia Hotel to be dominated by male sex is 169 people out of a total of 233 
respondents. This shows that those who stay at Narapati Indah Sharia Hotel are people who come to Bandung with a business orientation. In addition, they are also participating in trainings and seminars from the companies where they work which are held at Narapati Indah Sharia Hotel.

Table 1.2

Age Profile of Respondents

\begin{tabular}{|c|c|c|}
\hline Age & Frequency & Percentage (\%) \\
\hline$<30$ years & 3 & 1.29 \\
\hline $31-40$ years & 93 & 39.91 \\
\hline $41-50$ years & 120 & 51.50 \\
\hline$>50$ years & 17 & 7.30 \\
\hline Total & $\mathbf{2 3 3}$ & $\mathbf{1 0 0}$ \\
\hline
\end{tabular}

Source: Data Processing Results, 2018

Based on the table above it can be seen that the number of guests staying at Narapati Indah Sharia Hotel is dominated by guests between the ages of 41-50 years as many as 120 people. This shows that Islamic hotels are still in demand by adults and young people are not yet interested in visiting and staying at sharia hotels. In this case adults prioritize comfort and enjoy worship in lodging with the concept of sharia.

Table 1.3

Monthly Income of Respondents

\begin{tabular}{|c|c|c|}
\hline Monthly Income & Frequency & Percentage (\%) \\
\hline$<1$ million & 0 & 0.00 \\
\hline $1-2$ million & 2 & 0.86 \\
\hline $2.1-3$ million & 42 & 18.03 \\
\hline $3.1-4$ million & 161 & 69.10 \\
\hline$>5$ million & 28 & 12.02 \\
\hline Total & $\mathbf{2 3 3}$ & $\mathbf{1 0 0}$ \\
\hline
\end{tabular}

Source: Data Processing Results, 2018

Based on the table above it can be seen that the characteristics of respondents based on monthly income, obtained results that guests who stay in sharia hotels are dominated by people who have 3.1-4 million in income as many as 161 people $(69.10 \%)$ of the total respondents as many as 233 people.

Table 1.4

Last Education of Respondents

\begin{tabular}{|c|c|c|}
\hline Last Education & Frequency & Percentage (\%) \\
\hline Elementary & 2 & 0.86 \\
\hline Secondary & 10 & 4.29 \\
\hline High School & 30 & 12.88 \\
\hline Diploma & 27 & 11.59 \\
\hline Graduate & 139 & 59.66 \\
\hline Postgraduate & 37 & 15.88 \\
\hline Total & $\mathbf{2 3 3}$ & $\mathbf{1 0 0}$ \\
\hline
\end{tabular}

Source: Data Processing Results, 2018

Based on the table above, it can be seen that respondents based on the latest education, obtained results that many guests who stay in sharia hotels are guests who have a final education of 139 people (59.66\%) of the total respondents as many as 233 people. This is in line with the number of guests with male gender who stay with the interests of work and business matters. 
Table 1.5

Origin of Respondents

\begin{tabular}{|c|c|c|}
\hline Origin & Frequency & Persentase (\%) \\
\hline From Bandung & 80 & 34.33 \\
\hline Outside Bandung & 153 & 65.67 \\
\hline Total & $\mathbf{2 3 3}$ & $\mathbf{1 0 0}$ \\
\hline
\end{tabular}

Source: Data Processing Results, 2018

Based on the table above, it can be seen that many guests in Narapati Indah Sharia Hotel are from outside Bandung, namely 153 people (65.67\%) out of a total of 233 respondents. There are not many people in Bandung alone who are interested in sharia hotels as a place to stay. Guests from outside Bandung who come to Bandung with a variety of interests are more dominant and interested in staying at sharia concept hotels.

Diagram 1.1

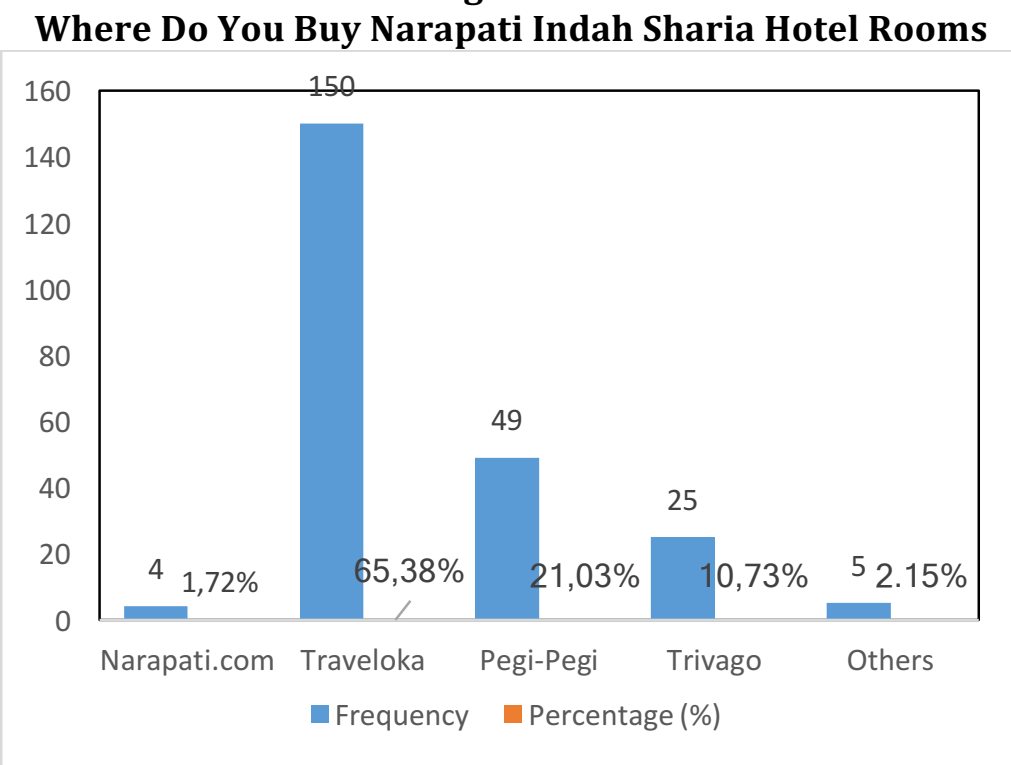

Source: Data Processing Results, 2018

Based on the table above it can be seen that Traveloka still dominates as a room service provider site or online travel agent that many guests use to order or buy rooms at Narapati Indah Sharia Hotel, shown 150 people out of a total of 233 respondents. It is unfortunate that the www.narapati.com website is not very optimal for its users. So it is still very dependent on hotel room service providers or online travel agents.

\section{Respondents' response to E-Commerce at Narapati Indah Sharia Indah Hotel Bandung}

The e-commerce variable consists of 21 question items, where each question item consists of 5 alternative respondent answers, based on the results of data processing, the following results are obtained: 
Table 2.1

Respondents Response on E-Commerce at Narapati Indah Sharia Indah Hotel Bandung

\begin{tabular}{|c|c|c|c|c|c|c|c|c|c|}
\hline \multirow{2}{*}{ No. } & \multirow{2}{*}{ Questions } & \multicolumn{5}{|c|}{ Alternative Answer } & \multirow[t]{2}{*}{$\begin{array}{l}\text { Total } \\
\text { Score }\end{array}$} & \multirow[t]{2}{*}{$\begin{array}{l}\text { Amount of } \\
\text { Sample }\end{array}$} & \multirow[t]{2}{*}{ Average } \\
\hline & & SA & $\mathbf{A}$ & $\begin{array}{c}\mathbf{N} \\
\text { A/D }\end{array}$ & D & SD & & & \\
\hline 1. & $\begin{array}{l}\text { Hotel prices offered by } \\
\text { Narapati Indah Sharia } \\
\text { Hotel are in accordance } \\
\text { with the advantages and } \\
\text { facilities obtained. }\end{array}$ & 59 & 81 & 76 & 17 & 0 & 881 & 233 & 3.78 \\
\hline 2. & $\begin{array}{l}\text { The price of the hotel has } \\
\text { been stated on the Narapati } \\
\text { Indah Sharia Hotel website. }\end{array}$ & 56 & 84 & 73 & 20 & 0 & 875 & 233 & 3.76 \\
\hline 3. & $\begin{array}{l}\text { The price of the Narapati } \\
\text { Indah Sharia Hotel is } \\
\text { cheaper than other hotels } \\
\text { contained in Bandung }\end{array}$ & 59 & 87 & 61 & 26 & 0 & 878 & 233 & 3.77 \\
\hline 4. & $\begin{array}{l}\text { Narapati Indah Sharia } \\
\text { Hotel always hold events to } \\
\text { display products and } \\
\text { services }\end{array}$ & 47 & 87 & 75 & 23 & 1 & 855 & 233 & 3.67 \\
\hline 5. & $\begin{array}{l}\text { Narapati Indah Sharia } \\
\text { Hotel giving discounts that } \\
\text { are more intense than } \\
\text { other hotel competitors }\end{array}$ & 53 & 82 & 77 & 21 & 0 & 866 & 233 & 3.72 \\
\hline 6. & $\begin{array}{l}\text { Installation of banners and } \\
\text { promotional tools in } \\
\text { strategic places and within } \\
\text { the hotel environment }\end{array}$ & 46 & 90 & 77 & 19 & 1 & 860 & 233 & 3.69 \\
\hline 7. & $\begin{array}{l}\text { Availability of brochures } \\
\text { about the facilities offered } \\
\text { by the inn while in Narapati } \\
\text { Indah Sharia Hotel }\end{array}$ & 67 & 88 & 67 & 11 & 0 & 910 & 233 & 3.91 \\
\hline 8. & $\begin{array}{l}\text { Complete information } \\
\text { about the location and } \\
\text { price of the hotel }\end{array}$ & 63 & 99 & 52 & 19 & 0 & 905 & 233 & 3.88 \\
\hline 9. & $\begin{array}{l}\text { Information about the } \\
\text { location and price of the } \\
\text { hotel can be accessed } \\
\text { through the website of } \\
\text { Narapati Indah Sharia } \\
\text { Hotel }\end{array}$ & 46 & 91 & 78 & 17 & 1 & 863 & 233 & 3.70 \\
\hline 10. & $\begin{array}{l}\text { Consumers are satisfied } \\
\text { with the invasion of } \\
\text { products provided by } \\
\text { Narapati Indah Sharia } \\
\text { Hotel }\end{array}$ & 57 & 77 & 84 & 15 & 0 & 875 & 233 & 3.76 \\
\hline 11. & $\begin{array}{l}\text { Consumption will continue } \\
\text { to use e-commerce to } \\
\text { purchase service products } \\
\text { at Narapati Indah Sharia } \\
\text { Hotel }\end{array}$ & 28 & 107 & 83 & 15 & 0 & 847 & 233 & 3.64 \\
\hline 12. & $\begin{array}{l}\text { The narapati Indah Sharia } \\
\text { Hotel website provides } \\
\text { product information that } \\
\text { consumers need. }\end{array}$ & 51 & 92 & 69 & 20 & 1 & 871 & 233 & 3.74 \\
\hline 13. & $\begin{array}{l}\text { Narapati Indah Sharia } \\
\text { Hotel always improve the }\end{array}$ & 53 & 82 & 74 & 24 & 0 & 863 & 233 & 3.70 \\
\hline
\end{tabular}




\begin{tabular}{|c|c|c|c|c|c|c|c|c|c|}
\hline & $\begin{array}{l}\text { quality of service to } \\
\text { consumers }\end{array}$ & & & & & & & & \\
\hline 14. & $\begin{array}{l}\text { The narapati Indah Sharia } \\
\text { website is very accessible }\end{array}$ & 32 & 99 & 75 & 27 & 0 & 835 & 233 & 3.58 \\
\hline 15. & $\begin{array}{l}\text { I feel happy with product } \\
\text { information Narapati Indah } \\
\text { Sharia Hotel via an easily } \\
\text { accessible network }\end{array}$ & 64 & 99 & 52 & 18 & 0 & 908 & 233 & 3.90 \\
\hline 16. & $\begin{array}{l}\text { With e-commerce, making } \\
\text { transaction at the hotel } \\
\text { Narapati Indah Sharia } \\
\text { Hotel become easier }\end{array}$ & 44 & 91 & 80 & 17 & 1 & 859 & 233 & 3.69 \\
\hline 17. & $\begin{array}{l}\text { With e-commerce, can get } \\
\text { the price information in } \\
\text { Narapati Indah Sharia } \\
\text { Hotel without going there }\end{array}$ & 60 & 86 & 72 & 15 & 0 & 890 & 233 & 3.82 \\
\hline 18. & $\begin{array}{l}\text { E-commerce allows me to } \\
\text { purchase narapati Indah } \\
\text { Sharia Hotel products } \\
\text { anywhere }\end{array}$ & 30 & 92 & 93 & 18 & 0 & 833 & 233 & 3.58 \\
\hline 19. & $\begin{array}{l}\text { Through E-commerce I can } \\
\text { make a purchase of } \\
\text { Narapati Indah Sharia } \\
\text { Hotel products at any time }\end{array}$ & 20 & 95 & 79 & 39 & 0 & 795 & 233 & 3.41 \\
\hline 20. & $\begin{array}{l}\text { Service price information is } \\
\text { always updated quickly if } \\
\text { there is a change }\end{array}$ & 66 & 97 & 52 & 18 & 0 & 910 & 233 & 3.91 \\
\hline 21. & $\begin{array}{l}\text { Information about the } \\
\text { services that I got on the } \\
\text { website, suitable after } \\
\text { making a purchase }\end{array}$ & 52 & 92 & 68 & 20 & 1 & 873 & 233 & 3.75 \\
\hline & Average Total & \multicolumn{8}{|c|}{78.33} \\
\hline & Average & \multicolumn{8}{|c|}{3.73} \\
\hline & Criteria & \multicolumn{8}{|c|}{ Good } \\
\hline
\end{tabular}

Source: Data Processing Results, 2018

Based on the table above, it can be seen that the respondent's answer to e-commerce variables is good. This means that transactions conducted by hotel guests with the Narapati Indah Sharia Hotel hotel have been established, the process of buying and selling is done by both through the internet information network, such as through the Narapati Indah Sharia Hotel website and other hotel room service provider websites mentioned. The highest average score on ecommerce variable is the availability of brochures about the facilities offered by the inn while in Narapati Indah Sharia Hotel, this means that in addition to using e-commerce media, the hotel provides brochures that can be obtained by hotel guests, brochures It contains all the facilities that can be enjoyed at the hotel, this brochure is made as attractive as possible to introduce the facilities owned by the hotel with the aim that people are interested, besides this brochure is also useful for hotel guests to recommend to other parties, while the lowest score on e-commerce variables is through e-commerce I can purchase Narapati Indah Sharia Hotel products at any time, this is due to frequent disruptions to Narapati Indah Sharia Hotel's sites and advertisements, so that consumers find it difficult to purchase products via the internet.

\section{Respondents Response about Brand Awareness on Narapati Indah Sharia Indah Hotel Bandung}

Brand awareness variables consist of 10 questions, in which each question item consists of 5 alternative answers, based on the results of data processing, the following results are obtained: 
Table 3.1

Respondents Response about Brand Awareness on Narapati Indah Sharia Indah Hotel Bandung

\begin{tabular}{|c|c|c|c|c|c|c|c|c|c|}
\hline \multirow{2}{*}{ No. } & \multirow{2}{*}{ Questions } & \multicolumn{5}{|c|}{ Alternative Answer } & \multirow{2}{*}{$\begin{array}{l}\text { Total } \\
\text { Score }\end{array}$} & \multirow{2}{*}{$\begin{array}{c}\text { Amount } \\
\text { of Sample }\end{array}$} & \multirow{2}{*}{ Average } \\
\hline & & SA & A & $\begin{array}{c}\mathbf{N} \\
\mathbf{A} / \mathbf{D}\end{array}$ & D & SD & & & \\
\hline 1. & $\begin{array}{l}\text { Narapati Indah Sharia } \\
\text { Hotel is not widely known } \\
\text { by many people }\end{array}$ & 18 & 100 & 85 & 28 & 2 & 803 & 233 & 3.45 \\
\hline 2. & $\begin{array}{l}\text { Many people who do not } \\
\text { know that Narapati Indah } \\
\text { Sharia Hotel, is one hotel } \\
\text { that offers good facilities } \\
\text { at affordable prices }\end{array}$ & 73 & 79 & 50 & 29 & 2 & 891 & 233 & 3.82 \\
\hline 3. & $\begin{array}{l}\text { Do you know Narapati } \\
\text { Indah Sharia Hotel is a } \\
\text { hotel located in the city of } \\
\text { Bandung }\end{array}$ & 60 & 83 & 74 & 16 & 0 & 886 & 233 & 3.80 \\
\hline 4. & $\begin{array}{l}\text { Do you know Narapati } \\
\text { Indah Sharia Hotel } \\
\text { through hotel } \\
\text { banners/billboards } \\
\text { installed or on the } \\
\text { website }\end{array}$ & 30 & 90 & 95 & 18 & 0 & 831 & 233 & 3.57 \\
\hline 5. & $\begin{array}{l}\text { Do you buy a room at } \\
\text { Narapati Indah Sharia } \\
\text { Hotel because it has more } \\
\text { benefits compared to } \\
\text { other hotels }\end{array}$ & 74 & 79 & 48 & 30 & 2 & 892 & 233 & 3.83 \\
\hline 6. & $\begin{array}{l}\text { Narapati Indah Sharia The } \\
\text { hotel is known for its } \\
\text { quality of service and } \\
\text { facilities not because its } \\
\text { price }\end{array}$ & 54 & 83 & 77 & 19 & 0 & 871 & 233 & 3.74 \\
\hline 7. & $\begin{array}{l}\text { Every time I want to stay } \\
\text { at the hotel, I always stay } \\
\text { at Narapati Indah Sharia } \\
\text { Hotel }\end{array}$ & 32 & 101 & 75 & 25 & 0 & 839 & 233 & 3.60 \\
\hline 8. & $\begin{array}{l}\text { Hotels that have good } \\
\text { facilities and affordable } \\
\text { prices are Narapati Indah } \\
\text { Sharia Hotel }\end{array}$ & 19 & 101 & 84 & 27 & 2 & 807 & 233 & 3.46 \\
\hline 9. & $\begin{array}{l}\text { Hotels that always appear } \\
\text { in my mind for the first } \\
\text { time are Narapati Indah } \\
\text { Sharia Hotel }\end{array}$ & 72 & 81 & 48 & 30 & 2 & 890 & 233 & 3.82 \\
\hline 10. & $\begin{array}{l}\text { I often stay at Narapati } \\
\text { Indah Sharia Hotel }\end{array}$ & 22 & 107 & 83 & 19 & 2 & 827 & 233 & 3.55 \\
\hline & Total Average & & & & & & 64 & & \\
\hline & Average & & & & & & 67 & & \\
\hline & Criteria & & & & & & ent & & \\
\hline
\end{tabular}

Source: Data Processing Results, 2018 
Based on the table above, it can be seen that the average respondent's answer to the brand awareness variable is $3.67 \%$ that is frequent, this means that guests are aware of the existence of Narapati Indah Sharia Hotel, is one of the sharia hotels in the city of Bandung. The highest average score on the e-brand awareness variable is to buy a hotel room at Narapati Indah Sharia Hotel can provide more benefits compared to other hotels, this is because in addition to its affordable price, narapati Indah Sharia Hotel has complete facilities that can spoil its guests . While the lowest score on the brand awareness variable is that Narapati Indah Sharia Hotel is not widely known by many people.

Based on the results of testing hypotheses, the influence of e-commerce on brand awareness, the results obtained 6.298 , then compared with the value of table with percentage of $5 \%$ and $233-2=231$ so that it obtained t table 1.970 , due to the results of $6.298>1.970$ and significance $0.000<0.05$ then Ho is rejected and accepted. Thus it can be concluded that e-commerce has a significant influence on brand awareness in Narapati Indah Sharia Hotel with a total effect of $33.5 \%$.

\section{CONCLUSION}

Based on the results of research on the influence of e-commerce on brand awareness of Sharia Hotels in Bandung, the following conclusions were obtained:

1. E-commerce at Narapati Indah Sharia Hotel has gone well. This was demonstrated by the transactions made by hotel guests with the existing Narapati Indah Sharia Hotel hotel, where there was a buying and selling process carried out by both through the internet information network, such as through the Narapati Indah Sharia Hotel website and the other hotel room service provider website like traveloka, pegi-pegi, trivago and others.

2. Brand awareness in Narapati Indah Sharia Hotels in the frequent category, this means that consumers are aware of the existence of Narapati Indah Sharia Hotel, is one of the hotels in the city of Bandung.

3. E-commerce has a significant influence on brand awareness on Narapati Indah Sharia Boutique Hotel \& Convention, with a magnitude of 33.5\%.

\section{Reference}

Aaker, David. 1991. Managing Brand Equity; Capitalizing on the Value of Brand Name. New York: Free Press Amstrong, G. \& Kotler. P. 1997. Prinsip-prinsip pemasaran. First Edition. Jakarta: Erlangga

Arikunto, Suharsimi. 1998. Prosuder Penelitian Suatu Pendekatan Praktek. Jakarta: Rineka Cipta

A Shimp, Terence. 2007. Periklanan Promosi ( Aspek Tambahan Komunikasi Pemasaran Terpadu). Vol. I, Translated Edition, Jakarta: Erlangga

Bilson, Simamora. 2001. Memenangkan Pasar dengan Pemasaran Efektif dan Profitabel. First Edition. Jakarta: Gramedia Pustaka Utama

Daniel, E., dan Storey, C. 1997, Online banking: Strategic and management challenges, Long Range Planning, Vol. 30, No.6.

Darmadi Durianto, Sugiarto, Lie Joko Budiman. 2004. Brand Equity Ten, Jakarta: Gramedia Pustaka Utama Gelder, S.V. 2005. Global Brand Strategy. London. Kogan page

Gian G Maulana, Rispiana, 2015, Sistem Informasi Pelayanan Jasa Tour and Travel Berbasis Website Electronic Commerce Studi Kasus Ninetours Indonesia, Online Journal. Reka Integra IISN: 2338-5081, No. 01, No. 03, January 2015, Industrial Engineering Major, Engineering Faculty, National Institute of Engineering, Bandung

Ghozali, Imam. 2007. Multivariate Analysis with SPSS Program. Fourth Edition. Badan Penerbit University of Diponegoro. Semarang

Ghozali, Imam. 2011. Multivariate Analysis with SPSS Program. Fourth Edition. Badan Penerbit University of Diponegoro. Semarang 
Gujarati, D.N. 2012. Dasar-dasar Ekonometrika, Terjemahan Mangunsong, R.C., Salemba Empat, Second Book, Fifth Edition, Jakarta

Hair, J. F., Black. W. C., Babin. B. J.; and Anderson. R. E. (2010), Multivariate Data Analysis, 7th ed. Pearson Prentice Hall, New Jersey

Hamill, J. and Gregory, K. 1997. Internet Marketing in the Internationalisation of UK SME's. Journal of Marketing Management 13

Husein, Umar. 2011. Metode Penelitian Untuk Skripsi dan Tesis Bisnis. Eleventh Edition. Jakarta: Raja Grafindo Persada

Hoffman, D. L. dan T. P. Novak. 1996. Marketing in Hypermedia ComputerMediated Environments: Conceptual Foundations, Journal of Marketing, Vol.60, No. 3

Janita. 2005. Inspirasi Bisnis: Perspektif Baru Dalam Strategi Branding, Bisnis, dan Karir. Jakarta: Amara Books Joreskog, K.G \& Sorbom, Dag 1993. Lisrel 8: Structural Equation Modelling with the Simplis Command Language, Chicago, SSI Inc

Kapferer, Jean Noel. 2008. Strategic Brand Management. 2nd ed. New York. Free Press.

Kaser, Ken. 2012. Advertising and Sales Promotion. United States of America: Cengage Learning.

Kotler, Philip. 2009. Manajemen Pemasaran. Jakarta: Erlangga

M. Suyanto, 2003. Strategi Periklanan pada E-Commerce Perusahaan Top Dunia. Andi Yogyakarta

M. Rayhan Janitra, 2003, Hotel Sharia Konsep dan Penerapan, Jakarta: Raja Grafindo Persada

Nana Sudjana. 2009. Penilaian Hasil Proses Belajar Mengajar. Bandung: Remaja Rosdakarya

Novak, T. P, D. L. Hoffman, D.L., dan Y. F. Yung. 2000. Measuring The Customer Experience in Online Environments: A Structural Modeling Approach. Marketing Science, Vol. 19, No. 1

Schultz, D.C., \& Barnes, B.E. (1999). Strategic brand communication campaigns. USA: NTC Busi - ness Books. 